\title{
0181 THE SAFETY OF NIGERIAN ROADS
}

E Osawe, ${ }^{*}$ G Osawe Correspondence: Federal Road Safety Corps, National Uniform Licensing Scheme, Ojodu-Isheri Road, Ikeja Lagos, PMB 16 Shomolu Lagos, Nigeria PMB 16, Nigeria

\subsection{6/ip.2010.029215.181}

The paper attempts to look into the causes of road crashes leading to deaths on African roads with Nigeria, Bode Saadu road as a case study. It falls along the major highway linking the Southern Seaports with the Northern part of the country. It has been listed as one of the 23 most dangerous roads in the world. The paper also enumerates causes of crashes in the country. It also looks at the establishment of the Federal Road Safety Corps as the Federal Government lead agency and its proffered solution and resolve to reduce the occurrence of road traffic crashes and its severity through the use of the 6Es

intervention strategies approach. The road factor remains an important issue in road safety in Nigeria.

Environmental This study shows that the roads are in a state of disrepair with rough and undulating surfaces, bridges require maintenance, dangerous spots, Traffic on the roads far exceeds the original designs.

Mechanical The roads are dotted with broken down heavy duty vehicles without warning sign, use of expired tyres etc.

Human It was shown that human factor determines violations which are causes of crashes. The proper licensing of drivers and vehicles is a key to safety and security. It is expected that with the solution proffered about $13 \%$ reduction in crashes casualties can be achieved. FRSC has a 6-point approach to the problem called 6Es: Engineering, Enlightenment, Environment, Education, Enforcement, Evaluation: Methodology of study entails the administration of questionnaires, diagnostic interview and data analysis. 